\title{
POSSIBLE MEDIATION OF WOUND-INDUCED RESISTANCE BY ENDOPHYTES OF PERENNIAL RYEGRASS
}

\author{
T.L. BULTMAN ${ }^{1}$ and M.R. MCNEILL ${ }^{2}$ \\ ${ }^{1}$ Division of Science, Truman State University, Kirksville, MO 63501, U.S.A. \\ ${ }^{2}$ New Zealand Pastoral Agriculture Research Institute Ltd., P.O. Box 60, Lincoln
}

Fungal endophytes of grasses have often been found to provide defence for their hosts against herbivores. We tested if simulated herbivore damage to endophyte (Neotyphodium lolii) - infected ryegrass (cv. Nui) induces elevated resistance to adult Argentine stem weevil (Listronotus bonariensis). Four weeks after germination, half of all potted perennial ryegrass plants were damaged by removing half of their tillers. Five days following damage, sections of two leaf blades were harvested from separate undamaged tillers from each plant (blades were not harvested from regrowth tissue). Blades from remaining tillers were paired (damaged and undamaged plants) within Petri dishes for infected and uninfected plants. Feeding by weevils on blades was visually assessed after 5, 24, and $48 \mathrm{~h}$. Feeding was significantly lower $(\mathrm{P}<0.5-\mathrm{P}<0.01)$ on blades from infected, damaged plants than it was on blades from infected, undamaged plants for all three time periods. The same trend did not hold for uninfected plants, except for the $48 \mathrm{~h}$ period $(\mathrm{P}<0.05)$. Results suggest that, in addition to constitutive resistance, endophytes may also provide their hosts with wound-induced resistance. However, microscopic inspection of seeds revealed a low infection rate $(23 \%)$ by $N$. lolii. Levels of peramine alkaloids in infected plants were also very low, with concentrations in undamaged and damaged leaf tissue of 3.55 and $1.31 \mathrm{ppm}$, respectively. Given the low peramine levels in the infected plants, the effect of $N$. lolii on L. bonariensis may have been caused by as yet unidentified non-alkaloid mycotoxins.

\section{THE EFFECT OF BUCKWHEAT ON ABUNDANCE OF THE LEAFROLLER PARASITOID DOLICHOGENIDEA TASMANICA IN A BLENHEIM VINEYARD}

\author{
L. BERNDT and P. HASSAN
}

\section{Ecology and Entomology Group, PO Box 84, Lincoln University}

Leafrollers (Lepidoptera: Tortricidae) are an economically important pest of grapes in New Zealand. The larvae attack leaves and buds, and the damage caused to fruit significantly reduces the value of the crop. At present organophospates are commonly used to control leafroller, however these generalist pesticides also kill off natural enemies and are toxic to humans. There is increasing pressure from New Zealands' export wine markets to reduce pesticide use and develop sustainable viticultural practices. The encouragement of the pests' natural enemies is an important part of this process. The provision of floral resources is a possible means to enhance the parasitoids of leafroller. In this study, buckwheat (Fagopyrum esculentum) planted in the vine undergrowth increased the abundance of the leafroller parasitoid Dolichogenidea tasmanica. Buckwheat was planted in mid row strips at Squire Estate vineyard, Blenheim in December 1998. From 25 January to 19 March, 1999, yellow sticky traps were used to trap D. tasmanica in the vines, and numbers caught in control and buckwheat areas were compared. Parasitoid abundance was significantly higher $(\mathrm{P}<0.05)$ in buckwheat plots $($ mean $=6.47)$ compared to control plots $(4.22)$. 